\title{
RECENT DEVELOPMENTS
}

\section{LABOR RELATIONS: STANDARDS ESTABLISHED FOR ISSUANCE OF BARGAINING ORDERS BASED ON AUTHORIZATION CARDS}

In NLRB v. Gissel Packing Co., ${ }^{1}$ the United States Supreme

Court held that elections were not the sole means of authorizing unions as bargaining representatives and that unambiguous authorization cards are reliable indicatórs of employee sentiment unless union solicitors indicate that the cards will be used only to obtain an NLRB election. The Court also held that the "good faith doubt" test is no longer applicable in determining whether a bargaining order should issue to compel an employer to recognize a union that claims representative status based upon authorization cards signed by a majority of the employees. Rather, the Court held that the commission of "serious unfair labor practices" that "tend to preclude the holding of a fair election" will justify the issuancc of a bargaining order. ${ }^{2}$ ln each of the four cases consolidated here, ${ }^{3}$ employers had refused to bargain on the grounds that authorization cards signed by a majority of the employees were inherently unreliable indicators of the employees' sentiments, and that, therefore, the union had no basis to demand recognition. In each case, unfair labor practice charges filed by the union resulted in either preventing an NLRB election or setting aside an election already won by the employer. The NLRB had issued an order to bargain in each case after finding that the employers entertained no good faith doubt of the union's majority status.4 The Court of Appeals for the First Circuit enforced

\footnotetext{
1395 U.S. 575 (1969).

${ }^{2}$ Id. at 600 . The Court also rejected an employer's claim that restrictions in the Act violated his freedom of speech. Id. at 616-20.

${ }^{3}$ General Steel Products, Inc. v. NLRB. 398 F.2d 339 (4th Cir. 1968); NLRB v. Heck's, Inc., 398 F.2d 337 (4th Cir. 1968): NLRB v. Gissel Packing Co., 398 F.2d 336 (4th Cir. 1968); Sinclair Co. v. NLRB, 397 F.2d 157 (1st Cir. 1968).

'Heck's, Inc., 65 L.R.R.M. 1635 (N.L.R.B. 1967), enforcement granted in part and denied in part per curiam, 398 F.2d 337 (4th Cir. 1968); Sinclair Co., 65 L.R.R.M. 1087 (N.L.R.B. 1967), enforced. 397 F.2d 157 (1st Cir. 1968); Gissel Packing Co.. 157 N.L.R.B. 1065 (1966), enforcement granted in part and denied in part per curiam. 398 F.2d 336 (4th Cir. 1968); General Steel Products, Inc., 157 N.L.R.B. 636 (1966), enforcement granted in part and denied in part per curiam, 398 F.2d 339 (4th Cir. 1968).
} 
this order in NLRB v. Sinclair Co., ${ }^{5}$ but the Court of Appeals for the Fourth Circuit denied enforcement in the other three cases. Enforcement was denied on the ground that an election constitutes the only valid basis for finding an obligation to bargain on the employer's part unless the employer knew, by some means other than the cards themselves, that a majority of the employees favored the union. ${ }^{6}$ Further, the Fourth Circuit held in two cases that the cards were such inherently unreliable indicators of employee opinions that distrust of them could serve as the basis of an employer's good .faith doubt of the union's majority.? Upholding the bargaining orders, the Supreme Court affirmed the First Circuit but reversed the Fourth Circuit.

It is not entirely clear that Congress intended to permit employees to designate bargaining representatives by any means other than an NLRB election or that a bargaining order might issue where an election had not been held. Section 9(c) of the original National Labor Relations Act stated that the Board could use elections or "any other suitable method" of certifying a union." The 1947 amendments, however, deleted the phrase "any other suitable method," and allowed an employer to petition for an election after being presented with a bargaining demand. ${ }^{10}$ Committee reports on the 1947 bill also indicated that the employer was assured of the right to petition for an election subsequent to a recognition demand. ${ }^{11}$ Most circuits, noting that certification of the union is not a prerequisite for an employer's duty to bargain, ${ }^{12}$ have

\footnotetext{
; 397 F.2d 157 (1st Cir. 1968).

- General Steel Products, Inc. v. NLRB. 398 F.2d 339 (4th Cir. 1968); NLRB v. Heck's, Inc., 398 F.2d 337 (4th Cir. 1968); NLRB v. Gissel Packing Co., 398 F.2d 336 (4th Cir. 1968).

' NLRB v. Heck's, Inc., 398 F.2d 337 (4th Cir. 1968); NLR B v. Gissel Packing Co., 398 F.2d 336 (4th Cir. 1968).

* National Labor Relations Act, ch. 372, \$ 9(c), 49 Stat. 449, 453 (1935), as amended, 29 U.S.C. $\$ 159$ (c) (1964).

' Labor Management Relations Act, 29 U.S.C. \$ 159(c) (1964), formerly' ch. 372, \$9(c), 49 Stat. 449,453 (1935).

${ }^{10} / d$.

"S. Rep. No. 105, 80th Cong., 1st Sess., pt. 1, 25 (1947); H.R. Rep. No. 245, 80th Cong., Ist Sess. 35 (1947).

12 Section 8(a)(5) makes it an unfair labor practice for an employer to refuse to bargain with the "representative of his employees" as designated subject to section 9(a). Section 9(a) states that representatives "designated or selected" by a majority of the employecs shall be the exclusive representatives of all the employees. At no point does the Act state that the union must be certified for section 8(a)(5) to come into operation. Labor Management
} 
held that employees may designate their representatives by means other than an election. ${ }^{13}$ In these circuits, almost any means of showing majority support for a union is acceptable, including participation in strikes, ${ }^{14}$ picketing, ${ }^{15}$ and authorization cards.${ }^{16}$ In most circumstances, ${ }^{17}$ once a majority of the employees designates a bargaining agent by any of these means, it is an unfair labor practice for an employer to refuse to bargain with that representative, ${ }^{18}$ and pursuant to section 10 (c) the Board may order an employer to cease and desist from this unfair labor practice. ${ }^{19}$ The Fourth Circuit, however, has held that because of the 1947 amendments an election is the only basis for an employer's duty to bargain ${ }^{20}$ but it has noted a possible exception where "outrageous" unfair labor practices have made a fair election impossible. ${ }^{21}$ Gissel presented the Supreme Court with an opportunity to resolve this conflict among the circuits as to what effect Congress intended the amendments to have on the issuance of bargaining orders where no valid election has been held.

The circuit courts have differed on the reliability of authorization cards and on the circumstances which will justify

Relations Act, 29 U.S.C. $\$ \$ 158(a)(5) \& 159$ (a) (1964), formerly ch. $372, \$ \$ 8(5) \& 9$ (a), 49 Stat. 449 (1935); NLRB v. Sehon Stevenson \& Co., 386 F.2d 551, 555 (4th Cir. 1967) (Sobeloff, J.. concurring).

${ }^{13}$ E.g.. NLRB v. Tom's Supermarket, Inc., 385 F.2d 198 (7th Cir. 1967); NLRB v. Decker, 296 F.2d 338 (8th Cir. 196I).

" E.g., Lebanon Steel Foundry v. NLRB. 130 F.2d 404, 407 (D.C. Cir.), cert. denied, 317

U.S. 659 (1942). See also Century Mills, Inc., 5 N.L.R.B. 807 (1938).

is E.g. NLRB v. World Carpets, Inc., 403 F.2d 408 (2d Cir. 1968).

${ }^{16}$ E.g.. United Mine Workers v. Arkansas Oak Flooring Co., 35I U.S. 62, 69 (1956); Franks Brothers Co. v. NLRB. 137 F.2d 989 (Ist Cir.), affd, 32I U.S. 702 (1943).

"See notes 24-36 infra and accompanying text, dealing with exceptions where an employer has a good faith doubt of the union's majority or where the union's majority is obtained through improper means.

ix E.g.. NLRB v. George Groh \& Sons, 329 F.2d 265, 268-69 (10th Cir. 1964); NLR B v. Dahlstrom Metallic Door Co., 112 F.2d 756 (2d Cir. 1940). Further, if the employer has committed unfair labor practices, a bargaining order may be granted even though no union request, and thus no refusal, to bargain has been made. J.C. Penney Co. v. NLRB, 384 F.2d 479, $485-86$ (10th Cir. 1967); Western Aluminum of Oregon, Inc., [44 N.L.R.B. I19] (1963).

19 Labor Management Relations Act, 29 U.S.C. $\$ 160$ (c) (1964), formerly ch. 372, $\$ 10$ (c), 49 Stat. 449 (1935).

${ }^{20}$ See NLRB v. S.S. Logan Packing Co., 386 F.2d 562 (4th Cir. 1967); note 6 supra. The Supreme Court rcjected this approach in United Mine Workers v. Arkansas Oak Flooring Co., 351 U.S. 62 (1956).

${ }^{21}$ NLRB v. S.S. Logan Packing Co., 386 F.2d 562, 568-70 (4th Cir. 1967). 
issuance of a bargaining order. While most circuits regard authorization cards as sufficiently reliable to serve as a basis for an employer's bargaining obligation, the Fourth Circuit has held that the cards are so inherently unreliable that an employer may in good faith refuse to bargain on the strength of them. ${ }^{22}$ The reasons which courts give for this position include the group pressures on the employee to sign a card, the fact that the employer's side is not usually presented as it would be in an election campaign, and the possibilities of coercion and misrepresentation by the union's solicitor. ${ }^{23}$ To prevent union misrepresentation from restricting employees' free choice, the Board held in Cumberland Shoe Corp. ${ }^{24}$ that the card would be invalidated if the union solicitor represented that the card would be used solely to obtain an NLRB election. This requirement was rigidly construed so as to uphold cards which, although giving the impression that an election would be held, did not explicitly state that the cards would only be used to obtain an election. ${ }^{25}$ Several circuits have refused to follow Cumberland Shoe, and some of the circuits accepting the rule have been critical of the Board's rigid application of it. ${ }^{26}$ On the related question of the circumstances under which a bargaining order may issue, the Board held in Joy Silk Mills, Inc. ${ }^{27}$ that an employer will not be compelled to bargain if his refusal of the union's recognition demand was made because of a good faith doubt that the union enjoyed majority support among the employees. An employer could not hope to successfully plead good faith doubt if he committed unfair labor practices subsequent to his refusal to bargain. ${ }^{28}$ Joy Silk and subsequent cases placed on the employer the duty to show

\footnotetext{
" Id.: .VLR B v. Sehon Stevenson de Co.. 386 F.2d 551 (4th Cir. 1967). Other circuits share this view: NLRB v. S.E. Nichols Co., 380 F.2d 438 (2d Cir. 1967): Engineers \& Fabricators. Ine. v. NLRB. 376 F.2d 482 (5th Cir. 1967).

$\approx$ NLRB v. S.S. Logan Packing Co., 386 F.2d 562 (4th Cir. 1967). See also Comment, L'nion Atuliorization cards. 75 YALE L.J. 805, 823-28 (1966).

"1 144 ...L.R.B. 1268 (1963), enforced, 351 F.2d 917 (6th Cir. 1965).

" Gotham Shoe MIg. Co., 149 N.L.R.B. 862 (1964), enforced. 359 F.2d 684 (2d Cir. 1966). Sice also 75 Yat.l: L.J.. supra note 23, at 824-25.

${ }^{25}$ See note 22 supra and accompanying text. For criticism of the doctrine, see, e.g., NLRB v. Sandy s Stores. Ine.. 398 F.2d 268 (Ist Cir. 1968); NLRB v. Swan Super Cleaners, Inc. 384 1.2d 609 (6th (ir. 1967): 75 YALE L.J.. supra note 23. at 824-26.

$=85$ V.L.R.B. 1263 (1949), culorced. 185 F.2d 732 (1).C. Cir. 1950), cert. denict, 341 U.S. 914 (1951).

"Id. Sier Comment, limploler "Good Faith Dumbt." 116 U. PA. L. Rliv. 709, 715-16 (1968).
} 
good faith reasons for his refusal to bargain. ${ }^{29}$ This duty has been shifted to the General Counsel, and an employer need not give reasons for his doubt. ${ }^{30}$ But if the employer did give some reason other than doubt of the union's majority, such as an erroneous belief by the employer that he was not engaged in commerce within the meaning of the NLRA, most circuits found a violation of section $8(a)(5)$ even though the reason was advanced in good faith. ${ }^{31}$ Good faith doubt could be established in the Fourth Circuit, however, by merely expressing a general distrust of the reliability of authorization cards. ${ }^{32}$ In several circuits an employer's refusal to accept the findings of a disinterested third party that the cards were valid was originally held to be evidence of a lack of good faith doubt. ${ }^{33}$ Subsequent cases have, however, declined to infer bad faith from such a refusal. ${ }^{3+}$ Almost any unfair labor practice was sufficient, at one time, to call forth a bargaining order, ${ }^{35}$ but more recently only those tending to undermine the union's majority and thus interfere with the election processes have been held to justify a bargaining order ${ }^{36}$ In oral argument of Gissel before the Supreme Court, the NLRB indicated its latest position to be that good faith doubt is irrelevant and that a bargaining order will issue where unfair labor practices are committed which tend to preclude the

${ }^{20}$ Kellogg Mills, 147 N.L.R.B. 342 (1964), enforced, 347 1*.2d 219 (9th Cir. 1965); Snow \& Sons, 134 N.L.R.B. 709 (1961), enforced. 308 F.2d 687 (9th Cir. 1962); Joy Silk Mills, Inc. 85 N.L.R.B. 1263 (1949), enforced. 185 F.2d 732 (D.C. Cir. 1950), cert. denicd. 341 U.S. 914 (1951).

${ }^{20}$ Aaron Bros., 158 N.L.R.B. 1077 (1966).

${ }^{31} \mathrm{H} \&$ W Construction Co., I61 N.L.R.B. 852 (1966); Gordon, Union Authorizalion Cards and the Duty to Bargain. 19 L+Bor L.J. 201, 208 (1968); But see Sonora Sundry Sales, Inc., I6I N.L.R.B. 676 (1966), culorcement denied, 399 1:.2d 930 (9th Cir. 1968).

I NLRB v. S.S. Logan Packing (o.. 386 1.2d 562 (th (iir. 1967).

${ }^{3}$ E.g., NLRB v. Purity Food Stores, Inc., 354 F.2d 926 (Ist Cir. 1965); NLRB v. George Groh \& Sons, 329 F.2d 265 (10th (ir. 1964): Snow \& Sons. 134 N.L.R.B. 709 (1961). enforced, 308 F.2d 687 (9th (ir. 1962).

"Textile Workers Union of Imerica v. VI.RB. 386 1.2d 790 (2d (ir. 1967): Aaron Bros., 158 N.L.R.B. 1077 (1966); Strydel, Inc., 156 N.L.R.B. 1185 (1966); People's Serv. Drug. Stores, Inc., 154 N.L.R.B. 1516 (1965), enforcement denied, 375 F.2d 551 (6th Cir. 1967).

25 Snow \& Sons, 134 X..I..R.B. 709 (1961), enforced. 308 l-.2d 687 (9th (ir. 1962); sece Comment, The Authorization Card Dilemma. 13 VIt.1.. L. Ri:l. 564, 575 (1968); 75 YAl.1: L.J., supra note 23.

is People's Serv. Drug Stores, Inc. v. NLRB, 375 F.2d 551 (6th Cir. 1967); Aaron Bros., 158 N.L.R.B. 1077 (1966); Hammond \& Irving. Inc., 15t X.L.R.B. 107! (1965): Conment, Union Authorization Cards: A Reliable Basis for an NLRB Order to Bargain? 47 TEXAS L. REV. 87 (1968). 
holding of a fair election ${ }^{37}$ However, the Board contended that if the employer either had knowledge from some source other than the cards themselves that the union had majority backing or if the employer in refusing to bargain gave some reason other than doubt of majority support, the employer's refusal to bargain would still be a violation of section $8(a)(5){ }^{38}$ Thus, the trend has been away from a rigid application of the good faith doubt test. It was upon this disagreement over the inherent unreliability of authorization cards and the situations in which a bargaining order is appropriate that the Supreme Court rendered the Gissel decision.

The first portion of the Court's holding dealt with the employers' claims that elections are the sole source of an employer's bargaining duty, and that authorization cards are inherently unreliable. The Court held that Congress did not intend to restrict an employer's duty to bargain only to those situations where an election has been held, in enacting the 1947 amendments. Further, the Court held that authorization cards were sufficiently reliable to serve as the basis for a bargaining order. The opinion noted that cards may be the most effective way of assuring employee free choice when the employer has committed unfair labor practices which disrupt the election process. ${ }^{33}$ Rejecting the employer's argument that the employees could not make an informed choice without an election because the employer had no chance to present his side of the argument, the Court stated that employers usually do learn of the organization drive early enough to express their views. ${ }^{10}$ To the employers' claim that group pressures often cause an employee to sign a card even though he may not favor the union, the Court replied that the same pressures would likely be present in an election. ${ }^{41}$ The Court also found employee free choice to be adequately insured by the Board's Cumberland Shoe doctrine.12 Expressly restricting its opinion to unambiguous cards, ${ }^{43}$ the Court indicated that employees should be held responsible for what they

37395 U.S. at 594.

2s Id. For examples of reasons, other than good faith doubt of the union's majority status, which employers have given in refusing to bargain, see note 31 supra and accompanying text.

39395 U.S. at 602.

${ }^{10}$ Id. at 603.

"Id. at 603-04.

12 Id. at 606. See note 24 supra and accumpanying text for discussion of the Board's Cumberland Shoe doctrine.

$=395$ U.S. at 609. 
sign unless the solicitor's statements induce them to ignore the language above their signatures. The opinion warned, however, that an overly rigid application of the Cumberland Shoe doctrine is unacceptable and stated that the approach taken in General Steel Products, Inc. ${ }^{44}$ is the most rigid that the Court will accept. ${ }^{45}$

In the second portion of its holding, the Court announced the new test for determining when a bargaining order should issue:

If the Board finds that the possibility of erasing the effects of past practices and of ensuring a fair election (or a fair rerun) by the use of traditional remedies, though present, is slight and that employee sentiment once expressed through cards would, on balance, be better protected by a bargaining order, then such an order should issue . . . .

The Court emphasized that not every unfair labor practice has a sufficient impact on the election process to justify a bargaining order $^{47}$ and noted the Fourth Circuit's indication that a bargaining order might be issued where "outrageous" and "pervasive" unfair labor practices had such serious effects on employee choice that less drastic remedies could not make a fair election possible. ${ }^{48}$ The only effect of Gissel, the Supreme Court said, will be to permit a bargaining order to issue in "less extraordinary cases" marked by "less pervasive practices" which still tend to interfere with the election process. ${ }^{\$ 9}$

The Gissel opinion weighs the relative merits of authorization cards and NLRB elections as bases of an employer's obligation to bargain. While the cards are to be permitted in some situations, the balance is clearly in favor of elections. ${ }^{50}$ The opinion focuses on

1157 N.L.R.B. 636 (1968).

is 395 U.S. at 607-09. In this case, 97 cards were validated even though one or more of the following statements were made to the signers: that the cards would be used to get an election; that the signer could vote either for or against the union even though he had signed a card; and that the card would be kept secret and would be shown only to the NLRB for the purpose of obtaining an election.

to 395 U.S. at 614-15.

is Id. at 615 .

1x Id. at 613-14. The Court's Fourth Circuit reference was to NLRB v. S.S. Logan Packing Co., 386 F.2d 562 (4th Cir. 1967).

"395 U.S. at 614.

${ }^{2}$ See note 45 supra and accompanying text. In six cases since Gissel. the Board has used the Gissel test: Texaco, 1nc., 72 L.R.R.M. 1146 (N.L.R.B. 1969); Garland Knitting Mills, 72 L.R.R.M. 1112 (N.L.R.B. 1969); Marie Phillips, Inc., 72 L.R.R.M. 1103 (N.L.R.B. 1969); Snyder Tank Corp., 71 L.R.R.M. 1615 (N.L.R.B. 1969): Poughkeepsie Newspapers, Inc.. 71 
effectuation of employee free choice as the central goal and concludes that an election can best reflect that choice. This is essentially the approach taken by the Board in oral argument of Gissel, but it differs from the prior good faith test in several ways. Gissel deemphasizes the idea of using a bargaining order to punish employers for unfair labor practices, which was one of the goals of the good faith test..1 By focusing on the employer's motivation, the good faith test permitted bargaining orders in situations where a fair election might well have been held.:2 The Gissel test will not permit bargaining orders in such cases. The opinion suggests that an employer may have an absolute right to an NLRB election, absent any unfair labor practices other than the refusal to bargain itself, though the Court did not explicitly hold this. Taking the converse of the Gissel test, a bargaining order will not issue when a fair election is possible; thus an election is practically certain if the employer commits no unfair labor practices other than the refusal to bargain. Moreover, the Court relied on the idea that an employer may have an election if he has committed no serious misdeeds. ${ }^{53}$ Thus, it is probable that Gissel may be read to stand for the proposition that an employer may always refuse a union's demand to bargain and insist on an election, provided that he engages in no serious misconduct affecting the election climate.34 The Board, in oral argument, stated two exceptions to this proposition: where the employer knew from some source other than

L.R.R.M. 1584 (.N.L.R.B. 1969): V \& H Industries. 7 I L.R.R.M. 1549 (...L.R.B. 1969). Further, while three courts have allowed the Gissel tests: NLRB v. American Cable Systems, Inc., 414 F.2d 661 (5th Cir. 1969); Food Store Employees Local 347 v. NLR B, 413 F.2d 407 (D.C. Cir. 1969); NLRB v. Mink-Dayton, Inc., 72 L.R.R.M. 2232 (6th Cir. 1969); NLRB v. American Art Indus., 72 L.R.R.M. 2199 (5th Cir. 1969); two courts have refused to abandon the good faith test: NLR B v. C \& P Plaza Dep't Store, 414 F.2d 1244 (7th Cir. 1969); Krystyniak v. NLRB, 71 L.R.R.M. 3135 (3d Cir. 1969).

31 VLLR B v. James Thompson * (0.. 208 1.2d 743. 746 (2d (ir. 1953): Lecsnick, Establishment of Bargaining Rights Without an .NLRB Election, 65 МicH. L. REv. 851,855 (1967): 75 YaLt: L.J.. supra note 23.

: Aaron Bros., 158 X.L.R.B. 1077. 1079 (1966): Snow \& Sons, 134 X.L.R.B. 709 (1961), enforced. 308 1:.2d 687 (9h (ir. 1962): 116 U. P.. L. RI.V.. supra note 28: 75 Yall: L.J.. supra note 23, at 812-13.

$=395$ U.S. at 609.

st Three cases since Gissel appear to agree with this interpretation. Mechanical Specialties Co. v. NLRB, 414 F.2d 898 (9th Cir. 1969); NLRB v. American Cable Systems, Inc., 414 F.2d 661 (5th Cir. 1969); Food Store Employees Local 347 v. NLRB. 413 F.2d 407 (D.C. Cir. 1969). 
the cards themselves that the union had majority support, or where the employer gave some reason other than doubt of the union's majority for his refusal. ${ }^{\mathrm{g}}$ However, in the light of Gissel, these exceptions would appear to be short-lived. While each is relevant to an inquiry into the "good faith doubt" of an employer, neither is relevant to an inquiry into the best means of effectuating employee free choice. Although the upholding of the Cumberland Shoe doctrine means that fewer cards will be invalidated for solicitor misrepresentation in some circuits, ${ }^{, 56}$ the probable absolute right to demand an election reduces the significance of the cards to the employer, even though he can now be ordered to bargain on the basis of cards alone. This new emphasis on elections not only safeguards the worker from employer coercion as before but also protects him from union misrepresentation and coercion through the virtual certainty that the employer will obtain a secret ballot election.

\footnotetext{
ss See note 37 supra and accompanying text. For examples of reasons other than good faith doubt of the union's majority status, which employers have given in relusing to bargain, see note 31 supra and accompanying text.

see notes 24-26 supra and accompanying text.
} 